\title{
Domestic tourism and sustainability in an emerging economy: Brazil's littoral pleasure
} periphery

\author{
Abstract \\ The littoral pleasure periphery (LPP) is a major and expanding spatial feature of \\ Brazil that is dominated by almost 200 specialised coastal resorts, beachfront \\ metropolises and beachfront cities. It is notable in an emerging economy context for \\ the extent to which domestic forces have influenced its development, including not \\ just favourable geographic features but patterns of historical settlement, \\ modernisation processes, national culture, and geopolitical motivations. Reflecting \\ Brazil's economic and social dualities, the LPP exhibits two distinct models. The \\ southern LPP, like counterparts in the more developed world, is long-established and \\ displays an "organic" growth trajectory. The northern LPP is a hybrid of "organic" \\ and "induced" impulses exhibiting more rapid and largely planned growth manifested \\ in low density development. Despite efforts of a multi-partner regional tourism \\ initiative - the PRODETUR - to facilitate economic and social equity through targeted \\ tourism investment, the northern LPP resembles classic Third World LPPs where \\ mainly "non-white" local residents are often displaced by coastal development \\ involving "white" investors and tourists. Unsustainable tourism outcomes are \\ therefore indicated in both components of the Brazilian LPP, and minimal progression \\ toward an enlightened mass tourism ideal.
}

Keywords: sustainable tourism; enlightened mass tourism; regional disparities; PRODETUR; pleasure periphery; coastal resorts 


\section{Introduction}

Post-1950 global tourism has been dominated by tourists from advanced economies travelling to other advanced economies, to emerging economies, and domestically. These patterns, however, are eroding because of rapid development in emerging economies, which have increased their share of international arrivals from 6\% to 35\% between 1960 and 2007 (Weaver \& Lawton, 2014). Domestic tourism, which accounted for $83 \%$ of all tourist movements in 2008 , is also becoming more important in emerging economies (Pierret, 2011). In China and India, domestic tourist trips increased from 642 million and 320 million respectively in 1999 (Bigano, Hamilton, Lau, Tol, \& Zhou, 2007) to 1.61 billion (ChinaView, 2011) and 562 million in 2007 (India Brand Equity Foundation [IBEF], 2011).

The increased absolute and relative importance of tourism in emerging economies has implications for sustainable development, a process and objective which has dominated contemporary tourism discourses since 1990 through the construct of 'sustainable tourism' (Weaver, 2006). Neoliberal ideology has positioned the tourist flow from advanced to emerging economies as a major economic development facilitator, with Mitchelmturand Ashley (2009) lauding tourism as the largest voluntary transfer of wealth from rich to poor regions. Dependency and allied theorists, alternatively, have emphasised conventional mass tourism as perpetrator and perpetuator of underdevelopment (English, 1986; Lea, 1988). It was in this context that Turner and Ash (1975) articulated the "pleasure periphery" as an emerging configuration of spatially marginal regions mobilised to accommodate sea, sand and sun (3S) recreational demand from residents of advanced economies. This pleasure periphery associates with cultural commodification, social disruption, dependency, environmental degradation, profit repatriation, revenue leakage, seasonality and lowwage employment (Harrison, 2001). In the Caribbean and South Pacific it has been alleged to foster a "new kind of sugar" (Finney \& Watson, 1975) and a neo-colonial "plantation model" of tourism development (Weaver, 1988). Locally controlled and small-scale 'alternative tourism', accordingly, has been widely touted as more conducive to sustainability outcomes (Weaver, 2006).

Subsequent efforts to achieve sustainable development, however, have been impeded by the tendency of conventional and alternative tourism supporters to equate "sustainable tourism" with their own perspective (Hall, 1998), ignoring in such 'conflict-based dialectics' the contradictions inherent to each polarity (Weaver, 2014). Unconstrained mass tourism generates the "prime contradiction" of 
breached carrying capacities (Butler, 1980), while alternative tourism entails unrealistic and unrealised expectations, and depends on mass tourism systems such as transport (Pearce, 1992). The pleasure periphery, therefore, presents a constrained policy arena where alternative or conventional mass tourism are positioned as the only appropriate development model, regardless of residents' preferences. Weaver (2014), in response, aspirationally advocates resolution-based dialectics in which assets of mass tourism (economies of scale, competitive innovation) and alternative tourism (ethical imperative, place sensitivity) are amalgamated into enlightened mass tourism that achieves optimal triple bottom line outcomes. Geopolitical sustainability, moreover, is recognised as a fourth pillar which recognises the state's concurrent mobilisation of tourism to achieve geopolitical objectives such as internal stability and secure borders (Weaver, 2010).

Whether dictated by resolution- or conflict-based dialectics, sustainable tourism implementation however remains a "wicked problem", given innate complexities and lack of clarity on appropriate indicators, measurement protocols, thresholds and benchmarks. Weaver (2012) argues moreover that movement toward enlightened mass tourism can occur along organic, incremental and induced trajectories that each merit distinctive frames of reference. The first involves mass tourism destinations where attendant carrying capacities have been or are in danger of being breached as per Butler (1980), the second implicates alternative tourism destinations that aspire to accommodate higher visitation by expanding their carrying capacities, and the third considers "instant" resorts developed as growth poles in peripheral areas. Even more basically problematic in the present research context is the fact that knowledge of pleasure periphery patterns and dynamics is rudimentary, although the organic trajectory is usually assumed (with important "induced" exceptions, such as Cancún, Mexico). Pleasure periphery discourses mostly assume that affected venues are within economically emerging countries while tourists and investment originate in economically advanced countries, though Weaver's "plantation model" (1988) and Smith (1991) are among the few attempts to structure such spatial patterns. More consideration has been given to $3 \mathrm{~S}$ pleasure periphery development and structure in economically advanced countries, such as the United States, United Kingdom and Australia, where supply and demand are mainly domestic. Here, the focus is mostly on individual resorts (Agarwal, 2002; Barrett, 1958; Lavery, 1974; Pigram, 1977; Prideaux, 2004) or 
constituent elements such as the "recreational business district" (Stansfield \& Rickert, 1970). Among the few regional studies are Towner (1996) and Walton (1983), both focused on England.

Absent from the literature are situations where such mainly domestic impulses influence pleasure periphery development in emerging economies. According to Weaver (1998, p. 293), "internally induced core-periphery dynamics...have been neglected as a framework for the analysis of Third World tourism, as if domestic involvement in the national tourism sector were somehow assumed to be either implicitly benign, or negligible". Exceptions involve analyses of relationships between dominant and peripheral islands in small archipelagic states such as Trinidad and Tobago (Jordan, 2007; Weaver, 1998), Antigua and Barbuda (Weaver, 1998) and Malta (Boissevain, 1979; Chaperon \& Bramwell, 2013). Tourism therein reflects and reinforces longstanding inequitable internal core-periphery relationships, although the tourists are themselves mostly international. Beyond 3S contexts, domestic tourism in China's interior has been equated with "internal colonialism" that exacerbates inter-ethnic disparities and tensions (Oakes, 1995).

The global pleasure periphery is expanding into mountainous interiors, but $3 \mathrm{~S}$ tourism remains the fundamental dynamic in both its international and domestic manifestations (Gormsen, 1997). These leisure-oriented coastal tourism phenomena can therefore be designated as the "littoral pleasure periphery" (LPP), with "littoral" capturing the coastline itself as well as substantively if more indirectly impacted adjacent land and sea. Chinese domestic tourism, to illustrate, is moving beyond its traditional metropolitan focus to embrace "seaside" and "sunlust" destinations in the south (Liu \& Wall, 2003; Zhong, Zhang, \& Li, 2011). India's LPP is more embryonic, though coastal locales in Goa, Kerala and Tamil Nadu are designated for large-scale domestic tourism development (Rao \& Suresh, 2001). In Brazil, the 197 million domestic tourists reported for 2012 greatly exceeded the 5.8 million international visitors (Ministry of Tourism [MTUR], 2013). Brazil's LPP is wellestablished and driven by domestic dynamics, but little is known about its structure or sustainability. This knowledge gap is exemplified in Weaver and Lawton's (2014) review of the global pleasure periphery, which excludes coastal Brazil. We provide here, to our knowledge, the first analysis of a domestically-induced LPP within an emerging economy. We describe its geographical configurations, identify factors underlying its development, and discuss the resultant implications for sustainable tourism outcomes. 


\section{Demarcation of Brazil's littoral pleasure periphery (LPP)}

Demarcation method

That no known prior attempts to demarcate or analyse the Brazilian LPP have been made may be due to unreliable micro-level visitation data and the lack of a standard nomenclature for places of tourism concentration. Available accommodation units as a surrogate variable, moreover, is unfeasible given numerous informal and non-inventoried facilities, the importance of second and rented homes, substantial VFR (visiting friends and relatives) markets using residents' dwellings, and important day-only excursionist markets in some destinations. Alternatively, we focused on identifying localities where leisure tourism is indicated as important along multiple concurrent dimensions. This approach is embodied in the concept of tourism urbanisation, which characterises situations where growth has been driven primarily by mobilisation for the consumption of mass leisure tourism and related activities (Mullins, 1991). The tourist city that results from tourism urbanisation is manifested, firstly, in cities such as York (UK), Prague, Boston, Rio de Janeiro and Jerusalem where tourism is prominent in specific districts (often the urban core) but not dominant overall (Judd \& Fainstein, 1999). These we define as diversified tourist cities. Alternatively, a specialised tourist city occurs where tourism is dominant overall. These typically possess strong municipal tourism identities, low community cohesion, high resident transience, low wages and seasonality-related economic instability (Mullins, 1992). Such traits reflect or indicate potential for unsustainable environmental, economic and sociocultural outcomes, but further investigation is complicated by differences between countries. Tourism cities in the United States (Gladstone, 1998), for example, only partially resemble their counterparts in Australia (Mullins, 1991, 1992).

Coastlines, wherever located, merit specialised nomenclature, and we therefore designate specialised tourist cities in such locations as specialised coastal resorts. Diversified tourist cities of the coast are designated as beachfront metropolises if they have at least one million residents, and beachfront cities if under one million. Subsequently, we searched for population concentrations with at least 2,000 residents on the coast of Brazil where the economy and identity are explicitly and solidly focused on 3S tourism. To identify candidates, we first accessed the 2011 Mapograf publication Praias do Brazil ("Beaches of Brazil"). This comprehensive list of 2,190 beach destinations covers the entire 7,500 km coastline. Most are individual beaches or points of interest, so 
we focused on a more selective list of 275 populated beach localities included on an accompanying map. Each candidate location on this map was assessed by consulting relevant Internet sources (the first author is a native speaker of Portuguese) and by manually examining Google Earth ${ }^{\circledR} 2012$ imagery. We considered the presence of hotels, resorts or second home complexes, golf courses, marinas, and beach infrastructure (e.g. beach huts, access points, chairs). Eighty-seven places did not fit our specifications of a coastal tourism city, including river destinations, other inland places, and places lacking tourism infrastructure. However, nine new destinations were added where urban development extended beyond the "parent" urban center to include new beachfront neighbourhoods. Our final selection of 195 coastal tourism cities forms the basis for demarcating the Brazilian LPP.

\section{Spatial configurations}

Five beachfront metropolises account for $2.5 \%$ of the identified 195 tourism centers and are exemplified by Rio de Janeiro and its iconic Copacabana and Ipanema beaches (Table 1). Other prominent examples are Salvador, Recife and Fortaleza, which like Rio de Janeiro are state capitals and important centres for manufacturing and services other than tourism (Figures 1 and 2). These 195 destinations are located in 181 municipalities, with 11 municipalities having more than one tourist destination.

Ten of the identified 195 destinations (5.0\%) are beachfront cities (e.g. Olinda in Pernambuco state). All remaining places $(\mathrm{n}=180)$ are specialised coastal resorts, which we divided into five population sub-categories, i.e., 45 (25\%) with under 10,000 residents; (e.g. Galinhos in Rio Grande do Norte); 95 with 10-50,000 (53\%) (e.g. Lucena in Paraíba); 16 with 50-100,000 (8\%) (e.g. Laguna in Santa Catarina); 17 with 100,000- 250,000 (9\%) (e.g. Guarapari in Espírito Santo); and seven with more than 250,000 (4\%) (e.g. Guarujá in São Paulo). One allowed anomaly, Costa do Sauípe, is a tourist destination in the municipality of Mata de São João in the Northeast state of Bahia which is dominated by a freestanding beach mega-resort complex isolated from the nearest urban centre of Porto do Sauípe. The Northeast and North regions together account for $60 \%(n=116)$ of all the identified tourism cities, but tourist cities in the Southeast and South regions tend to be larger. For example, tourist cities above 50,000 population account for $63 \%$ of all tourist cities in the latter, but just $37 \%$ in the former (Table 1, Figure 1;2). 
INSERT TABLE 1 HERE

INSERT FIGURE 1 HERE

INSERT FIGURE 2 HERE

\section{Underlying factors}

At least five interrelated environmental, historical, economic, cultural and geopolitical factors account for the contemporary development of Brazil's domestically-dominated LPP (Figure 3).

\section{INSERT FIGURE 3 HERE}

\section{Physical environment}

Geology and meteorology are foundational to any LPP morphology, and in Brazil are exceptionally suitable for contiguous development. The coastline is dominated by beaches, many of exceptional aesthetic quality. Mangroves and estuaries around the Amazon delta, along with physical isolation, account for the relative lack of tourism cities in the extreme north. Brazil's extensive latitudinal range $\left(5^{\circ} \mathrm{N}-34^{\circ} \mathrm{S}\right)$ supports a tropical-to-subtropical climate with occasional destructive summer downpours but very low hurricane or tornado risk. Water temperatures grade accordingly, with development in the far south inhibited by cool summer temperatures spawned by proximity to the Antarctic Current. Occasional exposure to polar air masses also produces uncomfortably cold air temperatures. Tropical air temperatures, with year-round clear and warm water, make beaches in the Northeast the most attractive (TripAdvisor, 2013; Veja, 2007). Geologically, the littoral is flat or occupied by low hills or mountains, and tectonically stable (Nogueira \& Lima, 2004). Natural vegetation is mostly biodiverse Atlantic rainforest, residual fragments of which are protected.

\section{Historical population settlement and urban primacy}

Like the United States of America and Australia, historical European settlement patterns in Brazil were dictated by a dominant, accessible and relatively fertile coastline. Population expansion 
since the $16^{\text {th }}$ century can be modelled as spatial diffusion moving progressively inland from the coast, often along rivers. The coastal population itself continuously increased and became progressively more urbanised and spatially integrated. By 2010, 463 coastal counties accounted for just $8 \%$ of all Brazilian counties but $27 \%$ of the national population (or $>50$ million) (IBGE, 2011a). A related factor also dictated by the reality of an extensive coastline is a pattern of regional urban primacy. Numerous states were established along the coast to facilitate governance of the extensive coastline and its periphery, and a single dominant urban centre was typically established in each to serve as capital city and dominant port (e.g. Rio de Janeiro, Salvador, Natal, etc.).

The coast, driven by associated beachfront development, acquired a parallel primacy in tourism and presently accounts for approximately $30 \%$ of all hotels and resorts built in Brazil between 2006 and 2014 (BSH International 2008, 2011). Primate cities also emerged as dominant "local" destinations and markets, with Natal, Fortaleza, Recife, and Salvador in 2010 respectively accommodating $62 \%, 62 \%, 58 \%$ and $48 \%$ of all tourists in their host states (Fundação CTI/NE, 2013). Intrastate fidelity, wherein the primate city provides the largest domestic market for the state, has been highest in the South (62\%), followed by the Southeast (53\%) and Northeast (44\%). The southern states of Rio Grande do Sul and São Paulo had the highest percentages of intrastate tourists, with $88 \%$ and $73 \%$ respectively, due mainly to disadvantages in water and air temperature that dissuade visits from more favourably endowed states to the north. Such metropolitanised and regionalised origin-destination patterns help to explain why only $17 \%$ of all domestic overnight trips in 2011 were by air (FIPE/MTUR, 2012).

\section{Modernisation}

Domestic tourism in Brazil emerged as a major economic and social phenomenon during the 1950s, involving mainly visits to Rio de Janeiro by members of the elite and emergent middle class, and VFR visits to northern Brazil by northern migrants resident in southern Brazil (Becker, 1999; IBGE 2011a). Increasing participation in domestic short-haul leisure tourism characterises societies in incipient stages of industrialisation (Burton, 1995). In Brazil, this was facilitated by the expansion of industry beyond São Paulo and its integration with adjacent regions through the expansion of the road network (Pereira, 2008). Long established primate urban cities, especially in southern Brazil, became 
better connected with their hinterlands and adjacent regions, as did other coastal cities where attractive tourism opportunities were made available to increasingly affluent urban residents located within easy driving distance to beaches. Recognising the limited availability of economic opportunities, authorities in these coastal cities and states through the 1960s integrated tourism into their long-term development planning (Costa, Araújo, Cavalcanti \& Souza, 2008; Cruz, 2000), initiating a new urban hierarchy where coastal tourism cities played an increasingly prominent role.

Brazil's transition from an early industrialising to industrialised country since 1950 was paralleled by the growth in international tourist arrivals from an estimated 250,000 in 1970 to two million by 1995 (Diegues, 2001) and 5.8 million in 2012 (MTUR, 2013). The latter figure, however, is greatly exceeded by the more than 150 million domestic tourist trips, a participation rate associated with well-articulated industrialisation (Burton, 1995). Presently, Brazil is classified by the World Bank (2011) as an Upper Middle Income country, with a 2010 per capita GDP of US\$10,710, ranking it $82^{\text {nd }}$ of 227 monitored countries and dependencies. Though still an emerging economy, Brazil is now the world's $7^{\text {th }}$ largest economy (World Bank, 2013) and it has a "high" Human Development Index that positions the country at $85^{\text {th }}$ of 169 countries reported by the United Nations Development Programme (UNDP, 2013). Burton's (1995) model also indicates that such economic circumstances should dictate a high level of outbound travel by residents, and this has been the case, with outbound Brazilian tourists increasing from 537,000 in 1982 (UNWTO, 1987) to 5,305,000 in 2010 (UNWTO, 2012). This outflow, however, has complemented rather than undermined the still rapidly growing domestic tourism sector.

\section{Culture and national mythology}

Beaches, at least since the 1960s, have been the main domestic tourist attraction of Brazil (Diegues, 2001), and many Brazilians visit them regularly. This reflects not just their status as strategic domestic tourism resources, but also their role as a key national symbol and dimension of national mythology (Kane, 2010). The veranista, or person who spends their vacation on the beach, regardless of race, origin state, or economic status, is a national cultural tradition. Images of an idyllic and sexually charged beach culture also pervade the foreign marketing of Brazilian tourism (Bandyopadhyay \& Nascimento, 2010). In 2010, 62.5\% of surveyed international leisure visitors 
cited "sun and beaches" as their main reason for their vacation in Brazil (MTUR, 2012). For the Brazilian veranista, owning a property near the beach has long been an ideal, and second homes constitute an important complement to more traditional types of accommodation in most LPP tourism places (MTUR/FGV, 2014). With the construction industry responding enthusiastically to this collective impulse, second homes have played a key role in the expansion of the LPP (Pereira, 2003; Rodrigues, 1997). Within the 463 coastal counties, $9 \%$ of the 17.4 million dwelling units are only used occasionally (e.g. weekends, vacation), compared with $4.6 \%$ in inland/hinterland counties. In the tourist city of Balenário Camburiú (Santa Catarina state), this proportion is $30 \%$ (IBGE, 2011b).

\section{Geopolitics and government investment}

Brazil's economic development since 1950 has been profoundly influenced by federal government policies and actions, initially by the military dictatorship and then by subsequent civilian administrations. Persistent problems of regional inequity largely account for this intervention. Disparity has been and continues to be pervasive. Locally, agglomerations such as Rio de Janeiro and São Paulo are known for their infamous favelas (slums). At the state level, power and wealth are concentrated in the primate capital cities, and nationally the poorer north is distinguished from the richer south. The latter constitutes one of the world's widest and most persistent regional divides, with per capita income in São Paulo, the richest state, about six times higher than in Maranhão, the poorest (Silveiro-Neto \& Azzoni, 2006). Race features prominently at all levels. Centuries of miscegenation have created a racially complex society dominated by a mixed-race population and sanctioned social ideal (mestiçagem). However, semantics of "white" and "non-white" are still used to describe not only inclinations of physical appearance but also cultural, social and economic attributes that offer opportunities for crossing colour lines but continue informally to privilege the lighter-skinned (IBGE, 2008; Telles, 2004). Accordingly, residents of favelas, and northern Brazil, are more likely to identify or be labelled as "non-white". "Whites", in contrast, are less than half the population but $82.5 \%$ of the richest $1 \%$ (IBGE, 2010). Persistent underdevelopment is suggested by the $26 \%$ share of the 194.9 million Brazilians living below the official poverty line (IBGE, 2010). The 2010 Gini Index of family income places Brazil 
as the $12^{\text {th }}$ most inequitable of 136 reporting countries, with the lowest and highest family deciles accounting respectively for $1.2 \%$ and $42.5 \%$ of total consumption (CIA, 2011).

Federal government intervention indicates a desire to strengthen Brazil's national cohesion by using federal resources to reduce regional and racial inequities and encourage spatial and cultural integration. This longstanding priority also coheres with Brazil's parallel desire to be recognised internationally as an influential middle power and champion of development (Lima \& Hirst, 2006). Since the 1960s, tourism has been identified as being well-suited to stimulating economic development in the littoral of northern Brazil, which has subsequently received most related investments. The Northeast is especially important, containing 56\% of the 195 tourism cities identified here but receiving 79\% of tourism investment between 2006 and 2012, 78\% of the hotel rooms resulting from that investment, and $88 \%$ of affiliated direct employment (Table 2) (BSH International, 2008, 2011). Most private sector investment capital originates within Brazil, although the Northeast receives significant overseas investment from Spain, Portugal and Italy (BSH International, 2008, 2011).

\section{INSERT TABLE 2 HERE}

The first national tourism plans in the 1990s designated coastal growth nodes mainly in the Northeast, and encouraged domestic tourism as a vehicle for transferring wealth from southern to northern Brazil. To facilitate this, the Action Program for Tourism Development (PRODETUR)(“Programa de Desenvolvimento do Turismo”) was established in 1992 as a collaboration between state/local governments, domestic (i.e. Banco do Nordeste do Brasil BNB) and international (i.e. the Inter-American Development Bank - BID) financial agencies and tourism agencies (e.g. Ministry of Tourism) to promote development in the Northeast region (NE). Domestic tourism-related investment was identified as the primary vehicle promoting employment, education and infrastructure (i.e., transportation, communication, sanitation, environmental conservation, and cultural heritage) (BNB, 1995). PRODETUR/NE allocates funds to economically deprived localities identified as having tourism potential. In 2008, 50.6\% of its US\$760 million budget was allocated to "construction", and 30.6\% to airports (BSH International, 2009). 
Evidence of such tourism investment is immediately discernible in Brazil's Northeast, particularly Bahia state where many mega-resorts are being developed, though not at the scale of the existing Sauípe Complex. Further tourism investment injections are also anticipated for the region, with the Costa dos Coqueiros (a promotional tourism region) and the Baía de Todos os Santos, located within the greater Salvador area, receiving US\$3.2billion and US\$977 million respectively (Silva, Christiane \& Carvalho, 2009). Furthermore, hotel developments in Ilha de Cajaíba are expected to contribute US\$1.6 billion to the local economy and generate 10,710 jobs.

\section{Sustainability implications}

\section{Economic}

Coastal tourism development, stimulated in particular by PRODETUR/NE investment and deliberately situated as mass rather than alternative tourism, has been an important source of employment and income, especially for coastal communities in northern Brazil (Cardoso, 2005; IBGE, 2011b; Neto, 2003; Oliveira, 2007; Pegas \& Stronza, 2010). In Mata de São João (Bahia) and Maragogi (Alagoas) municipalities, the proportion of the local labour force employed in tourism reaches 53\% (IBGE, 2011c). PRODETUR investments since the mid-1990s have also greatly improved the infrastructure and access of hitherto isolated coastal municipalities, including those with under 10,000 residents, which accommodated $21.8 \%$ of all hotel development in the Northeast. Benefits for formerly isolated communities have included clean water, increased connectivity to power grids, sewage treatment and better roads that facilitate intrastate and regional integration (Andrade, 2008; Delgado, 2009). It is argued that improved infrastructure further benefits the poor by increasing marginal labour productivity and transportation affordability (Siegel \& Alwang, 2005). Tourism's emergence as a viable sector in the Northeast was also fortuitous because of structural and biophysical problems in the long-dominant agricultural sector. Mass tourism development in southern Bahia state in the late 1980s, for example, coincided with the destruction of the once dominant cocoa farming industry by the Moniliophtora perniciosa fungus (Oliveira, 2007).

There is countervailing evidence, however, that PRODETUR investment has not had a widespread poverty alleviation effect (Oliveira, 2008) and has disproportionately benefited more affluent Brazilians in northern destinations such as Rio Grande do Norte state (Siegel \& Alwang, 
2005), Itacaré (Oliveira, 2007) and Costa dos Coqueiros in Bahia state (Limonad, 2007; Pegas \& Stronza, 2010), and Aquiraz in Ceará state (Souza, 2005). In Bahia, capacity building and improved sanitation opportunities were provided mainly to high-end tourism businesses (Mattedi, 2008; Pegas \& Stronza, 2010). Tourism jobs, moreover, tend to be low-wage and seasonal. In the northern states of Pernambuco and Ceará, disproportionate benefit effects have been further skewed by the higher cost of living stimulated by tourism investment and expenditure, and by the limited tourism employment opportunities created for lower income residents (Souza, 2005; Technologia e Consultoria Brasileira S.A. [TC/BR], 2001). In nine of the 19 Bahia municipalities identified as tourism cities in our study, $50 \%$ or more of the population was below the poverty line during the early 2000s (IBGE, 2003). In contrast, only one of nine municipalities in the southern state of Rio Grande do Sul had a poverty incidence above 30\%. Persistent gaps in wealth between north and south were also evident in state capitals, with Maceió (58.37\%) and São Luís (54.8\%) in northern Brazil having the highest poverty rates, and Florianópolis (23.5\%) and Rio de Janeiro (23.9\%) in southern Brazil the lowest. In part, these disparities reflect intrastate and intraregional patterns of supply and demand. Although a substantial number of southern Brazilians vacation in the north, especially during winter, patterns of facility ownership indicate that the subsequent transfer of wealth benefits the northern elite far more than poor northerners (FIPE/MTUR, 2009).

\section{Sociocultural}

Positive sociocultural effects of tourism in the LPP include the use of PRODETUR funds in the northern state of Paraíba to restore cultural sites and assist with institutional development (Delgado, 2009). Investments in Bahia state have similarly created educational, capacity building and cultural conservation opportunities, such as the Tamarzinho Program which provides local youth with education opportunities about the local marine environment as well as interpretative skills to educate visitors about sea turtles and their habitat within the visitor center of the TAMAR Project, a sea turtle conservation initiative (Pegas, Coghlan \& Rocha, 2012). Notably, these efforts have been augmented by private initiatives from resorts, such as Companheiros do Txai in Itacaré which provides capacity building to local community members (Oliveira, 2007) and the Projeto Berimbau in Costa do Sauípe which supports the development of cooperatives as mechanisms to generate income for local 
communities and preserve local culture (Andrade, 2008; Andrade, Ribeiro, Góes \& Abreu, 2004). Such positive effects, however, appear to be considerably outweighed by sociocultural costs exacerbated by accelerated development. One type of cost is associated with migrant influx. The stability of many small coastal communities in Bahia state has been disrupted by the arrival of economic migrants and seasonal residents, especially since the 1990s (Pegas, Coghlan, Stronza \& Rocha, 2013). Two of these communities, Imbassaí and Praia do Forte, each have a permanent population of under 3,000 but an influx of 12,500 migrant workers associated with the construction of hotels and other tourism facilities (BSH International, 2008, 2011; SUINVEST, 2009 as cited in Silva et al., 2009).

Throughout northern coastal Brazil, such migrant flows are associated with increased cost of living, prostitution, illegal settlements, drugs and violence (Pegas, 2012; Quan \& Souza, 2002; Siegel \& Alwang, 2005). Seasonal residents such as second home owners tend to be wealthy residents of nearby primate urban centres such as Fortaleza (Ceará state), who cluster in exclusive gated communities (Vasconcelos \& Coriolano, 2008). There are also many non-Brazilian seasonal residents, with $40 \%$ and $35 \%$ of residential real estate units in Ceará and Rio Grande do Norte, respectively, purchased by foreigners (mainly Portuguese) in 2004 (BSH International, 2005). Such temporary residents are mostly "white", while most local people are "non-white".

Social and cultural disruption is also associated with widespread and continuing community displacements that have occurred because of coastal resort and second home development. In Bahia and Ceará states, tourism has triggered conflict between developers and villagers angered by loss of access to traditional fishing grounds and local beaches (Coriolano \& Mendes, 2009; Mattedi, 2008; Pegas \& Stronza, 2010; Quan \& Souza, 2002). Many villagers moved to the slums of Fortaleza, and others to spontaneous settlements 10-20 kilometres inland which provided access to employment in the resorts. Such problems have also occurred to a more limited extent in southern Brazil. In Santa Catarina and São Paulo, intensive and rapid tourism development led to the outmigration of local villagers due to increased cost of living and forced displacement (Carmo, Gadotti, \& Bóia, 1999). In Paraty and Ubatuba (São Paulo state), conflicts between locals and tourism developers had already occurred in the 1930s and were associated with the intensification of the real estate market and the privatisation of local beaches (Jonas, 2006). 


\section{Environmental}

The PRODETUR is associated with the conservation of 16,524 ha of coastal habitat in northern Brazil (Saab, 1999), including six protected areas in Bahia and one in Rio Grande do Norte, the conservation of nine lagoons and dune restoration programs in Ceará, and the restoration of the Reginaldo Salgadinho Valley in Maceió (PRODETUR, 2005). Such initiatives, which also include development zoning regulations, were intended to prevent uncontrolled tourism development and associated negative impacts, though their effectiveness has been questioned (Barbosa, Formagio \& Barbosa, 2010; Mattedi, 1999; Pegas, 2011). Clean water and improved sewage treatment can also be regarded as positive environmental outcomes for some areas, while environmental conservation initiatives have been promoted by the industry in states such as Santa Catarina to increase energy efficiency and reduce consumption (Bogo \& Dreher, 2007). Environmental costs are widespread, although many pre-date tourism and are associated with longstanding and pervasive poverty in northern states such as Alagoas (Araujo \& Bramwell, 2002). On land, illegal settlements and environmental degradation in areas of conservation importance in Pernambuco state (Northeast) were directly and indirectly attributed to tourism development (TC/BR, 2001). Similarly, tourism in parts of Bahia has been associated with littering, deforestation, water and air pollution, and sewage release in mangroves (Andrade, 2008; Limonad, 2007; Oliveira, 2007; Quan \& Souza, 2002). In Ceará state (Northeast), tourism has been implicated in illegal fishing, sedimentation, illegal development in protected areas, and mangrove/dune deforestation (Souza, 2005). Dune degradation has been observed in Pernambuco due to vegetation removal (Costa et al., 2008) and in Rio Grande do Norte due to poorly regulated off-road driving tours and littering (Siegel \& Alwang, 2005).

Such effects, again, are not confined to northern Brazil, with intensive tourism development in Santa Catarina and São Paulo inducing coastal habitat degradation and illegal settlement in protected areas (Carmo et al., 1999). In Balneário Camboriú, a major tourist city in Santa Catarina where second home acquisition was already evident in the 1920s, tourism development has contributed to water shortages, inadequate drainage systems, and severe summer congestion (Carmo et al., 1999). Water pollution adjacent to beaches is locally problematic throughout Brazil due mainly to inadequate sewage treatment. The highest number of polluted beaches occurs in Rio de Janeiro state (46 of 312 beaches), followed by São Paulo (34 of 261) and Bahia (15 of 238) (Flores, 2006). Higher pollution 
rates in the south can be attributed to more intensive beachfront development as well as aging infrastructure that reflects the longer involvement with tourism.

\section{Discussion}

The Brazilian LPP is an extensive and well-articulated linear region featuring almost 200 specialised coastal resorts, beachfront metropolises, and beachfront cities. Anticipated population growth (associated with Brazil's youthful demography) and economic development will stimulate continued expansion and intensification, and position the LPP as an increasingly dominant component of the Brazilian human landscape and major challenge for environmental, social and economic sustainability. A key to understanding and addressing this challenge is to appreciate that history, culture and economics in Brazil have conspired to create two distinct LPPs. The "southern LPP" is characterised by a deeper history of domestically propelled market-driven growth conducive to higher-density development, its tourist cities displaying mid- to late "development" dynamics of the tourism area life cycle. Markets and labour are both predominantly "white". As such, it resembles LPP configurations in other relatively more developed regions, such as Florida, England, Australia and Italy which all reflect Weaver's (2012) “organic” trajectory of tourism development. From a sustainability perspective, the southern LPP displays ample evidence of water pollution, seasonal congestion, urban sprawl and other localised negative environmental impacts consistent with the later stages of the classic tourism area life cycle. However, Weaver's (2014) contention that environmental or other crises can spawn an "arena of opportunity" leading to innovations conducive to more sustainable outcomes, salient in other "developed" LPPs, is not supported by evidence from southern Brazil. A trajectory toward enlightened mass tourism, accordingly, is not yet apparent, although those innovations (e.g. Benidorm) could serve as role models.

The "northern LPP" is more complex, exhibiting both "organic" and "induced" development impulses associated, in a more recent historical timeframe (i.e. since the 1980s), with the interplay of private and public sector actors. As with the southern LPP, and critically, these are also primarily domestic. Faced therefore with relatively few investment restrictions, private sector involvement has contributed to the development of an LPP that in many ways is displaying the unsustainable social and economic dynamics associated with classic Third World LPPs in the Caribbean and South Pacific. 
Beyond lower density and more rapid growth indicative of the earlier "development" stage, these dynamics include a geography of disparity where the prime coastline is being filled with exclusive second home and resort developments patronised mainly by "whites", while the near littoral is being increasingly mobilised as a mainly "non-white" low-wage labour reservoir, many residents of its largely spontaneous settlements having been displaced from coastal homes by tourism development. This race-imbued pattern of displacement to the near littoral strongly parallels what was earlier identified in Antigua (Weaver, 1988), and especially in the US state of South Carolina where domestic impulses similarly pertain (Weaver, 2007). Weaver $(1988,2007)$ argues that these settlements are an integral functional component of the classic Third World LPP given their essential function of providing convenient cheap labour.

What then are the sustainability implications for the northern LPP of the "induced" element, represented primarily by the Brazilian government through the PRODETUR? In principle, the latter should mitigate the influence of the private sector by embodying and enabling espoused national ideals of equity and equality. It cannot be denied that tourism development has provided much-needed employment for local residents and improvements in infrastructure (e.g. sewage treatment), but the same can be said for any classic Third World LPP; the involvement of a powerful and well-resourced domesticentity such as PRODETUR should entail added responsibilities and outcomes that transcend such basic improvements in resident quality of life. For geopolitical and other reasons, successive federal governments, through the PRODETUR, have deemed it strategically necessary to invest enormous resources in the development of integrated resorts and facilitating infrastructure in the north. This should be a great benefit arising from the north's political affiliation with the south. However, as seen, the economic and sociocultural outcomes, especially for poor northerners, are disappointing. Underlying factors manifest the disadvantages of this political affiliation. Similar to other Third World LPPs is a not negligible level of foreign (mainly European) investment and tourist visitation. However, most tourists are domestic. Many of these domestic tourists are southerners visiting second homes or resorts located often in gated enclaves that generate, economically, more leakages than linkages (Freitag, 1994). Those profiting are often southern investors or wealthier local northerners who are also strongly implicated as investors and intrastate tourists. Tourism, essentially, both reflects and reinforces the dominance of these wealthier citizens, and PRODETUR becomes a 
facilitator of this unsustainable dynamic through its apparent collusion with relatively unimpeded domestic market forces and "trickle-down" assumptions about the diffusion of wealth to poorer citizens. This is tangibly symbolised by the paradox of seaside resort complexes that are carefully master-planned to satisfy guests and investors but juxtaposed with nearby spontaneous settlements that are unplanned and effectively ignored despite their critical functional relationship with the resorts.

A simplified exegesis of the tourism situation in Brazil's northern LPP positions the PRODETUR as a theoretically "noble" domestic impulse that has failed to date in achieving its mandate of higher social and economic equity, in large part because of the parallel "nefarious" impulse of a domestic elite - both northern and southern - that has successfully mobilised this entity to further its own interests as investors or tourists. In Weaver's (2014) sustainability framework, the "organic" element represented by the private sector has essentially impeded the "induced" element, represented by government and PRODETUR, from attaining the enlightened mass tourism ideal that would embrace the dual goals of increased tourism revenue and social justice. Tourism, rather, serves to exacerbate entrenched and overlapping dichotomies of north/south, rich/poor, and white/non-white. To the extent that this might increase regional and social alienation, tourism is also implicated as a geopolitically unsustainable centrifugal activity that could threaten the longer-term viability of the Brazilian state.

The decoupling of the PRODETUR and the interests of the domestic elite is therefore one compelling if challenging way in which the northern LPP can manifest more sustainable economic and sociocultural outcomes. This might entail a greater emphasis on so-called community-based tourism projects, although Butcher (2007) and others have questioned the economic and social utility of such small-scale enterprises, and Weaver (2014) has contended that they need to be better integrated into conventional tourism systems to better achieve their economic potential. Partnerships have been cited as effective vehicles for facilitating development in destinations facing crisis conditions such as entrenched poverty, but the experience of the Costa Dourada integrated regional tourism initiative in the northern state of Alagoas indicates practical difficulties associated with the non-participation of "grassroots" actors, asymmetrical power relationships and the lack of a shared vision or objectives among participants, despite agreement on the desirability of securing 
PRODETUR funds (Araujo \& Bramwell, 2002). In any case, and unlike destinations such as Antigua and Fiji where investment and demand are international, it is notable that the capacity to achieve enlightened mass tourism exists within Brazil itself.

\section{Conclusion}

Our paper provides the first examination, to our knowledge, of a LPP dominated by domestic forces within an emerging economy. This Brazilian LPP, though informed mostly by domestic impulses, reveals itself to be a hybrid of developed-region and developing-region LPP types, reflecting the status of Brazil itself as a middle-income country with contrasting rich and poor personalities. With regard to sustainability outcomes, the southern LPP is similar to LPP configurations in the more developed world that reflect a dominantly "organic" growth trajectory. The northern LPP, in contrast, is itself a hybrid with similarities to the classic Third World LPPs that indicate the primacy of the free market "organic" component over the idealistic "induced" component, embodied in the PRODETUR, which formally aspires to redress longstanding social and economic disparities. Neither the induced nor organic trajectory, accordingly, indicates progress toward the attainment of an enlightened mass tourism ideal that amalgamates the best characteristics of mass and alternative tourism.

While the identification of the LPP's basic configuration was a relatively straightforward and objective matter, we were surprised by the lack of literature, in any language, on broader analyses of coastal tourism sustainability in Brazil. In that sense our paper is seminal. However, we are also more aware of the many avenues of constructive follow-up research that have now emerged, particularly given our rather pessimistic assessments of the future that arise from extrapolations of the current situation. Future research should build on the partnership research of Araujo and Bramwell (2002) to further investigate the politics of PRODETUR and other public sector entities, and their formal and informal linkages with Brazil's tourism developers and other elites, thus ascertaining the reasons for the disparity between the sustainability ideal and the reality. The emerging spatial pattern of "rich coast"/"poor littoral" also needs to be more systematically examined with accompanying ethnographic interrogations of residents at the case study level to identify the effects of these patterns on quality of life and attitudes toward the Brazilian state as a facilitator of development and object of loyalty. 


\section{List of Figures and Tables}

Figure 1: Tourism destinations in Southern Brazil (South and Southeast regions)

Figure 2: Tourism destinations in Northern Brazil (North and Northeast regions)

Figure 3: The five factors that influence the contemporary development of the Brazilian LPP

Table 1: LPP tourism places by type and region based on population numbers

Table 2: Tourism investment by state and region projected to open between 2006 and 2012 including the number of hotel rooms and direct jobs associated with these investments 
References

Agarwal, S. (2002). Restructuring seaside tourism: The resort lifecycle. Annals of Tourism Research, 29(1), 25-55.

Andrade, J. (2008). Programa Berimbau: Iniciativa político-institucional de regulação de conflitos socioambientais na área de influência de Costa do Sauípe-Bahia [Berimbau program: Political-institutional initiatives for the regulation of socioenvironmental conflicts in the Costa do Sauípe-Bahia area]. RAC-Eletrônica, 2, 426-448. Retrieved from http://www.anpad.org.br/diversos/trabalhos/EnANPAD/enanpad_2005/APS/2005_APSC906 $\underline{. \mathrm{pdf}}$

Andrade, J., Ribeiro, M., Góes, M., \& Abreu, F. (2004). Regulação de conflitos sócioambientais: O Programa Berimbau-BA [Regulation of socioenvironmental conflits: The Berimbau ProgramBA]. Meeting of the Associação Nacional de Pós-Graduação e Pesquisa em Ambiente e Sociedade (ANPPAS), 356-378. Retrieved from http://www.anppas.org.br/encontro_anual/encontro2/GT/GT15/celio.pdf

Araujo, L. \& Bramwell, B. (2002). Partnership and regional tourism in Brazil. Annals of Tourism Research, 29(4), 1138-1164.

Bandyopadhyay, R., \& Nascimento, K. (2010). Where fantasy becomes reality: How tourism forces made Brazil a sexual playground. Journal of Sustainable Tourism, 18(8), 933-949.

Barbosa, S., Formagio, C., \& Barbosa, R. (2010). Áreas protegidas, uso e ocupação do solo, qualidade de vida e turismo no litoral norte paulista: Algumas reflexões sobre o município de Ubatuba [Protected areas, use and land settlement, quality of life and tourism in the paulista north coast: Some reflexions about the municipality of Ubatuba]. Caderno Virtual de Turismo, 10(2), 121-137. Retrieved from file://C:/Users/s2766261/Downloads/439-1204-1-PB.pdf

Barrett, J. (1958). The seaside resort towns of England and Wales (Unpublished doctoral dissertation). University of London, London.

Becker, B. (1999). Políticas e planejamento do turismo no Brasil [Tourism policies and planning in Brazil]. In A. Carlos, R. Cruz \& E. Yazigi (Eds.), Turismo: Espaço, paisagem e 
cultura [Tourism: Space, landscape and culture] (pp. 181-192) (2nd ed.). São Paulo: HUCITEC.

Bigano, A., Hamilton, J., Lau, M., Tol, R., \& Zhou, Y. (2007). A global database of domestic and international tourist numbers at national and subnational level. International Journal of Tourism Research, 9(3), 147-174.

BNB (Banco do Nordeste do Brasil). (1995). Descrição, objetivos, metas e components [Description, objectives, goals and components]. Fortaleza: PRODETUR/NE. In Filho, F.C. (2002). Contribuições do turismo a economia brasileira [Tourism contributions to the Brazilian economy] (Unpublished doctoral dissertation). Universidade de São Paulo, Piracicaba.

Bogo, C., \& Dreher, M. (2007). Responsabilidade social empresarial: O emprego da Agenda 21 nas empresas turísticas da região da AMMVI [Corporate social responsibility: The implementation of the Agenda 21 by the tourism companies in the region of the AMMVI]. Dynamis, 15(1), 70-81. Retrieved from file://C:/Users/s2766261/Downloads/3731287-2-PB.pdf

Boissevain, J. (1979). The impact of tourism on a dependent island: Gozo, Malta. Annals of Tourism Research, 6(1), 76-90.

BSH International. (2005). Resorts no Brasil [Resorts in Brazil]. Retrieved from the BSH International website: http://www.slideshare.net/bshinternational/2005-resorts-no-brasil

BSH International. (2008). Investimentos no Brasil: Hotéis \& resorts 2008 [Investments in Brazil: Hotels and resorts 2008]. Retrieved from the BSH International website: http://www.bsh.com.br/sys/download/investimentos_2008.pdf.

BSH International. (2009). Guia de oportunidades de investimentos hoteleiros no Ceará - 2009 [Guide of hotel investment opportunities in Ceará - 2009]. Retrieved from the BSH International website: http://www.bsh.com.br/sys/download/ceara_2009.pdf

BSH International. (2011). Investimentos no Brasil: Hotéis \& resorts - 2011 [Investments in Brazil: Hotels and resorts 2011]. Retrieved from the BSH International website: http://www.bsh.com.br/sys/download/relatorio_investimentos_no_brasil_2011.pdf 
Burton, R. (1995). Travel Geography. London: Longman.

Butcher, J. (2007). Ecotourism, ngos and development: A critical analysis. London: Taylor \& Francis.

Butler, R. (1980). The concept of a tourist area cycle of evolution: Implications for management of resources. Canadian Geographer, 24(1), 5-12.

Cardoso, R. (2005). Dimensões sociais do turismo sustentável: Estudo sobre a contribuição dos resorts de praia para o desenvolvimento das comunidades locais [Social dimensions of sustainable tourism: Study about the contributions of beach resorts in the development of local communities]. (Unpublished doctoral dissertation). Escola de Administração de Empresas de São Paulo da Fundação Getúlio Vargas, São Paulo.

Carmo, E., Gadotti, G., \& Bóia, Y. (1999). Análise comparada da evolução de sítios turísticos: Santos (SP) e Balneáreo Camburiú (SC) [Comparative analysis of the evolution of tourism sites: Santos (SP) and Balneáreo Camburiú (SC)]. Turismo: Visão e Ação, 2(3), 27-40.

Retrieved from https://www6.univali.br/seer/index.php/rtva/article/view/1186

Chaperon, S., \& Bramwell, B. (2013). Dependency and agency in peripheral tourism development. Annals of Tourism Research, 40, 132-154.

ChinaView. (2011). Fact box: Basic facts about China's economy. Retrieved from the ChinaView website: http://news.xinhuanet.com/english/2008$\underline{08 / 06 / \text { content 8994009.htm }}$

CIA (Central Inteligence Agency). (2011). Factbook: Brazil. Retrieved from CIA website: https://www.cia.gov/library/publications/the-world-factbook/geos/br.html

Coriolano, L., \& Mendes, E. (2009). As interfaces do turismo nas praias de Jericoacoara e Tatajuba: Políticas, conflitos e gestões [The interfaces of tourism on the beaches of Jericoacoara and Tatajuba: Policies, conflicts and management]. Revista Turismo em Análise, 20(1), 96-115. Retrieved from http://www.revistas.usp.br/rta/article/download/14174/15992

Costa, M., Araujo, M., Cavalcanti, J., \& Souza, S. (2008). Verticalização da praia da Boa Viagem (Recife, Pernambuco) e suas consequências socioambientais [Verticalization of Boa Viagem beach (Recife, Pernambuco) and socioenvironmental consequences]. Revista da Gestão 
Costeira Integrada, 8(2), 2008-233. Retrieved from http://www.aprh.pt/rgci/pdf/RGCI128 Ferreira-da-Costa.pdf

Cruz, R. (2000). Política de turismo e território [Tourism policies and territory]. São Paulo: Editora Contexto.

Delgado, A. (2009). As ações do PRODETUR/NE I e suas implicaçôes para o desenvolvimento da Paraíba com base no turismo [PRODETUR/NE I actions and implications for tourism development in Paraíba]. Caderno Virtual de Turismo, 9(3), 32-43. Retrieved from http://www.ivt.coppe.ufrj.br/caderno/index.php?journal=caderno\&page=article\&op=viewFile \&path $\% 5 \mathrm{~B} \% 5 \mathrm{D}=345 \&$ path $\% 5 \mathrm{~B} \% 5 \mathrm{D}=220$

Diegues, A. (2001). Regional and domestic mass tourism in Brazil: An overview. In K. Ghimire (Ed.), The native tourist: Mass tourism within developing countries (pp. 55-85). London: Earthscan.

English, E. (1986). The great escape? An examination of north-south tourism. Ottawa: North-South Institute.

Finney, B., \& Watson, K. (Eds.). (1975). A new kind of sugar: Tourism in the Pacific. Honolulu: East-West Centre.

FIPE (Fundação Instituto de Pesquisas Econômicas)/ MTUR (Ministry of Tourism). (2009). Caracterização e dimensionamento do turismo doméstico no Brasil 2007 [Characterization and dimensionalization of domestic tourism in Brazil 2007]. Brasilia: Ministry of Tourism.

FIPE (Fundação Instituto de Pesquisas Econômicas)/ MTUR (Ministry of Tourism). (2012).

Caracterização e dimensionamento do turismo doméstico no Brasil 2010/2011: Relatório Eeecutivo produto 6 [Characterization and dimensionalization of domestic tourism in Brazil 2002 and 2006: Executive report product 6]. São Paulo: Ministry of Tourism.

Flores, M. (2006). O ciclo de vida do destino turístico: O estudo de caso do balneário de Búzios [The live cycle of a tourism destination: Balneario de Búzios case study]. In C. Carvalho and L. Barbosa (Eds.), Discussões e propostas para o turismo no Brasil: O observatório de inovação do turismo [Discussions and proposals for tourism in Brazil: the observatory for innovation in tourism] (pp. 157-181). Rio de Janeiro: SENAC. 
Freitag, T. (1994). Enclave tourism development: For whom the benefits roll? Annals of Tourism Research, 21(3), 538-554.

Fundação CTI/NE. (2013). Estatísticas: Indicadores do turismo no NE [Statistics: Tourism indicators in the NE]. Retrieved from the Fundação CTI/NE website: http://www.ctinordestedobrasil.com.br/estatisticas.html

Gladstone, D. (1998). Tourism urbanization in the United States. Urban Affairs Review, 34(1), 3-27.

Gormsen, E. (1997). The impact of tourism on coastal areas. GeoJournal, 42(1), 39-54.

Hall, C. (1998). Historical antecedents on sustainable development: New labels on old bottles? In C. M. Hall \& A. Lew (Eds.). Sustainable Tourism: A Geographical Perspective (pp. 13-24). London: Longman.

Harrison, D. (Ed.). (2001). Tourism and the less developed world: Issues and case studies. Wallingford: CABI International.

IBEF (India Brand Equity Foundation). (2011). Tourism and hospitality. Retrieved from the IBEF website: http://www.ibef.org/artdispview.aspx?in=74\&art id=29511\&cat_id=120\&page=1

IBGE (Brazilian Institute of Geography and Statistics). (2008). Características étnico-raciais da população: Um estudo das categorias de classificação de cor ou raça [Etnic-racial characteristics of the population: A study of the classification categories of color or race]. Retrieved from the IBGE website: http://www.ibge.gov.br/home/estatistica/populacao/caracteristicas raciais/PCERP200 $\underline{\text { 8.pdf }}$

IBGE (Brazilian Institute of Geography and Statistics). (2003). Censo demográfico 2000 e pesquisa de orçamentos familiares - POF 2002/2003 [Demographic census 2000 and household budget research - POF 2002/2003]. Retrieved from the IBGE website:http://www.ibge.gov.br/cidadesat/topwindow.htm?1

IBGE (Brazilian Institute of Geography and Statistics). (2010). Síntese de indicadores sociais: Uma análise das condições de vida da população brasileira - 2010 [Sintesis of social indicators: An analysis of the livelihood conditions of the Brazilian population 2010]. In Estudos \& Pesquisas: Informação Demografica e Socioeconômica, Vol. 27. Brasilia, Brazil: IBGE. 
Retrieved from the IBGE website:

http://www.ibge.gov.br/home/estatistica/populacao/condicaodevida/indicadoresminimos/sintes eindicsociais2010/SIS_2010.pdf

IBGE (Brazilian Institute of Geography and Statistics). (2011a). Reflexões sobre os deslocamentos populacionais no Brasil [Reflexions about population migrations in Brazil]. Rio de Janeiro, Brazil: IBGE. Retrieved from the IBGE website:http://ibge.gov.br/home/estatistica/populacao/reflexoes_deslocamentos/deslocame ntos .pdf

IBGE (Brazilian Institute of Geography and Statistics). (2011b). Atlas geográfico das zonas costeiras e oceânicas do Brasil [Geographical atlas of Brazil's coastal and oceanic zones]. Brasília, Brazil: IBGE. Retrieved from the IBGE website: http://biblioteca.ibge.gov.br/visualizacao/livros/liv55263.pdf

IBGE (Brazilian Institute of Geography and Statistics). (2011c). Pesquisa de serviços de hospedagem 2011: Municípios das capitais, regiões metropolitantas das capitais e regiões integradas de desenvolvimento [Research about hospitality services 2011: Counties, metropolitan regions and development integrated regions]. Retrieved from the IBGE website:ftp://ftp.ibge.gov.br/Comercio_e_Servicos/Pesquisa_Servicos_de_Hospedagem/2011/ psh2011.pdf

Jonas, M. (2006). Saberes e práticas na relação entre caiçaras e animais no sertão da fazenda (Picinguaba-Ubatuba,SP) [Knowledge and practices on the relationship between farm desert animals and the caiçara community (Picinguaba-Ubatuba, SP)] (Unpublished doctoral dissertation). Faculdade de Educação -Unicamp: Campinas. Retrieved from http://www.bibliotecadigital.unicamp.br/document/?view=vtls000386022

Jordan, L. (2007). Interorganisational relationships in small twin-island developing states in the Caribbean - The role of the internal core-periphery model: The case of Trinidad and Tobago. Current Issues in Tourism, 10, 1-32.

Judd D. \& Fainstein, S. (Eds.) (1999). The tourist city. Hartford: Yale University Press. 
Kane, S. (2010). Beach crime in popular culture: Confining the carnivalesque in Salvador da Bahia, Brazil. Sociology of Crime, Law and Deviance, 14, 243-262.

Lavery, P. (1974). Resorts and recreation. In P. Lavery (Ed.), Recreational Geography (pp.167-196). New York: Wiley.

Lea, J. (1988). Tourism and development in the third world. London: Routledge.

Limonad, E. (2007). O fio da meada: desafios ao planejamento e a preservação ambiental na Costa dos Coqueiros (Bahia) [Challenges in the development and environmental preservation at the Costa dos Coqueiros (Bahia)]. Revisa Electrónica de Geografia y Ciencias Sociales, 11(245), 1-16. Retrieved from http://www.ub.edu/geocrit/sn/sn-24540.htm

Liu, A., \& Wall, G. (2003). Human resources development for tourism in a peripheral island: Hainan, China. In S. Gössling (Ed.). Tourism and development in tropical islands: Political ecology perspectives (pp. 222-236). Cheltenham: Edward Elgar.

Mattedi, R. (1999). Planejamento e gestão do turismo e do meio ambiente na Bahia [Tourism and environmental planning and management in Bahia]. Gestão \& Planejamento-G\&P, 1, 1-21. Retrieved from http://revistas.unifacs.br/index.php/rgb/article/view/129/129

Mattedi, R. (2008). Pesquisa e planejamento ambiental no litoral norte da Bahia [Environmental research and planning on the north coast of Bahia]. Gestão \& Planejamento-G\&P, 1(3), 1-11. Retrieved from http://www.revistas.unifacs.br/index.php/rgb/article/viewArticle/147

Mitchell, J., \& Ashley, C. (2009). Can the private sector reduce poverty at scale? Evidence from the tourism value chain. Retrieved from the Commonwealth Ministers Reference Book website: http://www.odi.org.uk/resources/download/3644.pdf

MTUR (Ministry of Tourism). (2012). Estudo da demanda turística internacional 2005-2011 [International tourism demand study 2005-2011]. Retrieved from the MTUR website: http://www.dadosefatos.turismo.gov.br/export/sites/default/dadosefatos/demanda turi stica/downloads_demanda/Demanda_Turxstica_Internacional_-_Fichas_Sinteses_2005$\underline{2011 \quad \text { V2.pdf }}$ 
MTUR (Ministry of Tourism). (2013). Plano nacional de turismo: O turismo fazendo muito mais pelo Brasil 2013-2016. Retrieved from the MTUR website: http://www.turismo.gov.br/export/sites/default/turismo/o_ministerio/publicacoes/downloads_p ublicacoes/plano_nacional_2013.pdf

MTUR (Ministry of Tourism)/Fundação Getúlio Vargas (FGV). (2014). Sondagem do consumidor: Intençâo de viagem [Consumer survey: Intention to travel]. Retrieved from the MTUR website:http://www.dadosefatos.turismo.gov.br/export/sites/default/dadosefatos/conjuntura_ec onomica/sondagem_consumidor_viagem/downloads_sondagem_consumidor/SondagemMaio2 014.pdf

Mullins, P. (1991). Tourism urbanization. International Journal of Urban and Regional Research, 15(3), 326-342.

Mullins, P. (1992). Cities for pleasure: The emergence of tourism urbanization in Australia. Built Environment, 18(3), 187-198.

Neto, A. (2003). A responsabilidade socioambiental da indústria do turismo: Empreendimento Costa do Sauípe [The social and environmental responsibility of the tourism industry: The Costa do Sauípe enterprise] (Unpublished doctoral dissertation). Universidade de Brasília, Brazil.

Nogueira, L., \& Lima, C. (2004, May). Terra abençoada: Por que o Brasil tem poucos desastres naturais? [Blessed land: Why does Brazil has so few natural disasters?]. Revista Super Interessante. Retrieved from http://super.abril.com.br/ecologia/brasil-tem-poucosdesastres-naturais-444511.shtml

Oakes, T. (1995). Tourism in Guizhou: The legacy of internal colonialism. In A. Lew and L. Yu (Eds.), Tourism in China: Geographical, Political and Economic Perspectives (pp. 203-222). Boulder: Westview Press.

Oliveira, E. (2007). Impactos socioambientais e econômicos do turismo e as suas repercussões no desenvolvimento local: O caso do município de Itacaré-Bahia [Socioeconomic and environmental impacts of tourism and local development implications: The case of the Itacaré-Bahia municipality]. Interações: Revista Internacional de Desenvolvimento Local, 8(2), 193-202. Retrieved from http://www.scielo.br/pdf/inter/v8n2/a06v08n2.pdf 
Oliveira, F. (2008). As políticas de turismo no Brasil nos anos noventa [Brazilian tourism policies in the 90s]. Turismo em Análise, 19(2),177-200. Retrieved from http://www.revistas.usp.br/rta/article/view/14149/0

Pearce, D. (1992). Alternative tourism: Concepts, classifications, and questions. In V. Smith \& W. Eadington (Eds.). Tourism alternatives: Potentials and problems in the development of tourism (pp. 15-30). Philadelphia: University of Pennsylvania Press.

Pegas, F. (2011). Protecting biodiversity via ecotourism: The use of economic incentives as conservation tools. Paper presented at the VIII Brazilian Ecotourism Congress, São Paulo Brazil.

Pegas, F. (2012). Protecting sea turtles via ecotourism: The case of the TAMAR project in Praia do Forte, Bahia. In G. Lohmann \& D. Dredge (Eds). Tourism in Brazil: Environment, management and segments (pp. 108-122). New York: Routhledge.

Pegas, F., \& Stronza, A. (2010). Ecotourism and sea turtle harvesting in a fishing village of Bahia, Brazil. Conservation and Society, 8(1), 15-25.

Pegas, F., Coghlan, A., \& Rocha, V. (2012). An exploration of a mini-guide program: Training local children in sea turtle conservation and ecotourism in Brazil. Journal of Ecotourism, 11(1), 4855.

Pegas, F., Coghlan, A., Stronza, A., \& Rocha, V. (2013). For love or for money? Investigating the impact of an ecotourism programme on local residents' assigned values towards sea turtles. Journal of Ecotourism, 12(2), 90-106.

Pereira, M. (2008). Ordenamento do território, densidades hoteleiras e seus efeitos sobre a paisagem no litoral norte do estado da Bahia, trecho Forte-Sauípe [Territory layout, hotel density and their effects on the north coast landscape of Bahia, Forte-Sauípe stretch] (Unpublished master's thesis). Federal University of Brasilia, Brazil. Retrieved from http://repositorio.unb.br/bitstream/10482/4767/1/2008_MariaGracasBorjaGondimSantosPerei ra.pdf

Pereira, R. (2003). Formação sócio-espacial do litoral de Santa Catarina (Brasil): Gênese e transformações recentes [The socio-spacial formation of the Santa Catarina coast (Brasil): 
Genesis and recent transformations]. Geosul, 18(35), 99-129. Retrieved from https://periodicos.ufsc.br/index.php/geosul/article/view/13604/12471

Pierret, F. (2011). Some points on domestic tourism. World Tourism Organization UNWTO. Retrieved from http://unwto.org/en/opinion/some-pointsdomestic-tourism

Pigram, J. (1977). Beach resort morphology. Habitat International, 2, 525-541.

Prideaux, B. (2004). The resort development spectrum: The case of the Gold Coast, Australia. Tourism Geographies, 6(1), 26-58.

PRODETUR. (2005). Relatório final de projeto - Contrato de empréstimo N 841/OC-BR PRODETUR/NE I [Final report of the project - Loan contract N 841/OC-BR PRODETUR/NE I]. Retrieved from the Banco do Nordeste Brasileiro website: http://www.bnb.gov.br/content/aplicacao/prodetur/downloads/docs/docum_9_pcr_i.p $\underline{\mathrm{df}}$

Quan, J., \& Souza, M. (2002). Análise dos interessados para a Área de Proteção Ambiental Litoral Norte da Bahia: Uma ferramenta fundamental para a construção da gestão participativa [Analysis of local stakeholders of the Area of Environmental Protection Litoral Norte da Bahia: A fundamental tool for the development of participatory management]. In Annals of the III Brazilian Congress of Conservation Units. Fortaleza: Rede Nacional Pró-Unidades de Conservação: 167-176.

Rao, N., \& Suresh, K. (2001). Domestic tourism in India. In K. Ghimire (Ed.), The native Tourist: Mass tourism within developing countries (pp. 198-228). London: Earthscan.

Rodrigues, A. (1997). Turismo e espaço: Rumo a um conhecimento transdiciplinar [Tourism and space: Towards a transdisciplinary knowledge]. São Paulo, Brazil: Hucitec.

Saab, W. (1999). Considerações sobre o desenvolvimento do setor de turismo no Brasil [Considerations about tourism development in Brazil]. BNDES Setorial, Rio de Janeiro, 10, 285-312.

Siegel, P., \& Alwang, J. (2005). Public investments in tourism in northeast Brazil: Does a poor area strategy benefits the poor. World Bank, Latin America and Caribbean Region Sustainable Development Working Paper, 22: 1-11. Retrieved from the World Bank 
website: http://siteresources.worldbank.org/LACEXT/Resources/2585531123250606139/BR-Tourism Siegel COMPLETE.pdf

Silva, B., Christiane, B., \& Carvalho, S. (2009). Globalização, turismo e residências secundárias: O exemplo de Salvador-Bahia e de sua região de influência [Globalization, tourism and secondary homes: Example of Salvador-Bahia and its region of influence]. Revista Acadêmica Observatório de Inovação do Turismo, 4(3), 1-17. Retrieved from http://bibliotecadigital.fgv.br/ojs/index.php/oit/article/view/5748

Silveiro-Neto, R., \& Azzoni, C. (2006). Location and regional income disparity dynamics: The Brazilian case. Papers in Regional Science, 85, 599-613.

Smith, R.A. (1991). Beach resorts: A model of development evolution. Landscape and Urban Planning, 21, 189-210.

Lima, M., \& Hirst, M. (2006). Brazil as an intermediate state and regional power: Action, choice and responsibilities. International Affairs, 82(1), 21-40.

Souza, M. (2005). Análise do turismo em Aquiraz-Ceará: Politica, desenvolvimento e sustentabilidade [An analysis of the tourism in Aquiraz-Ceará: Policies, development and sustainability] (Unpublished master's thesis). Universidade Federal do Ceará. Fortaleza.

Stansfield, C., \& Rickert, J. (1970). The recreational business district. Journal of Leisure Research, 2, 213-225.

SUINVEST (Superintendência de Investimentos em Pólos Turísticos). (2009). Superintendência de investimentos em pólos turísticos [Office of investments in tourism destinations]. In Silva, I. , Alencar, C., \& S. Silva. (2009). Caracterização socioambiental das praias do município de Lauro de Freitas [Socio-environmental characterization of the beaches of the Lauro de Freitas municipality]. Geografica, 30(2), 327-348. Retrieved from http://www.bib.unesc.net/arquivos/75000/76300/11_76394.htm

TC/BR (Tecnologia e Consultoria Brasileira S.A.). (2001). Plano de desenvolvimento integrado do turismo sustentável para o Pólo Costa dos Arrecifes - Pernambuco, volume 1 [Integrated development plan of sustainable tourism for the Pólo Costa dos Arrecifes Pernambuco, volume 1]. TC/BR: Pernambuco, Brazil. Retrieved from 
https://www.bnb.gov.br/content/aplicacao/prodetur/downloads/docs/pe 1_resumo execu tivo 100708.pdf

Telles, E. (2004). Race in another America: The significance of skin color in Brazil. Princeton: Princeton University Press.

Towner, J. (1996). An historical geography of recreation and tourism in the western world 1540-1940. Chichester: Wiley.

TripAdvisor. (2013). Traveller's choice 2013: As 10 melhores praias - Brasil [Brazil's 10 best beaches]. Retrieved from TripAdvisor website:

http://www.tripadvisor.com.br/TravelersChoice-Beaches

Turner, L. \& Ash, J. (1975). The golden hordes: International tourism and the pleasure periphery. New York: St. Martin's Press.

UNDP (United Nations Development Programme). (2013). Brazil: Country profile- Human development indicators. Retrieved from the UNDP website: http://hdrstats.undp.org/en/countries/profiles/BRA.html

UNWTO (United Nations World Tourism Organization). (1987). Compendium of tourism statistics. Madrid, Spain.

UNWTO (United Nations World Tourism Organization). (2012). Compendium of tourism statistics: Data 2006-2010. Madrid, Spain.

Vasconcelos, F., \& Coriolano, L. (2008). Impactos sócio-ambientais no litoral: Um foco no turismo e na gestão integrada da zona costeira no estado do Ceará/Brasil [Coastal socioenvironmental impacts: A focus on tourism and on the integrated management of the state of Ceara's coastal zone]. Revista da Gestão Costeira Integrada, 8(2), 259-275. Retrieved from http://www.aprh.pt/rgci/pdf/rgci-134_vasconcelos.pdf

Veja. (2007). Praia: O melhor destino [Beach: the best destination]. Retrieved from Veja website: http://veja.abril.com.br/especiais/brasil_2007/p_018.html

Walton, J. (1983). The English seaside resort: A social history 1750-1914. Leicester: Leicester University Press. 
Weaver, D. (1988). The evolution of a "plantation" tourism landscape on the Caribbean island of Antigua. Tijdschrift voor Economische en Sociale Geografie, 79, 319-331.

Weaver, D. (1998). Peripheries of the periphery: Domestic tourism involvement in Tobago and Barbuda. Annals of Tourism Research, 25, 292-313.

Weaver, D. (2006). Sustainable tourism: Theory and practice. London: Butterworth-Heinemann.

Weaver, D. (2007). Resort structure and 'plantation' dynamics in Antigua and coastal South Carolina. In S. Agarwal \& G. Shaw. (Eds.), Coastal tourism resorts: A global perspective (pp. 204215). Clevedon: Channel View.

Weaver, D. (2010). Geopolitical dimensions of sustainable tourism. Tourism Recreation Research, 35(1), 45-51.

Weaver, D. (2012). Organic, incremental and induced paths to sustainable mass tourism convergence. Tourism Management, 33, 1030-1037.

Weaver, D. (2014). Asymmetrical dialectics of sustainable tourism: Toward enlightened mass tourism. Journal of Travel Research, 53, 131-140.

Weaver, D., \& Lawton, L. (2014). Tourism Management (5th ed.). Brisbane: Wiley Australia. World Bank. (2011). Data: Brazil. Retrieved from the World Bank website: http://data.worldbank.org/country/brazil

World Bank. (2013). Brazil overview. Retrieved from the World Bank Website: http://www.worldbank.org/en/country/brazil/overview

Zhong, S., Zhang, J., \& Li, X. (2011). A reformulated directional bias of tourist flow. Tourism Geographies, 13(1), 129-147. 


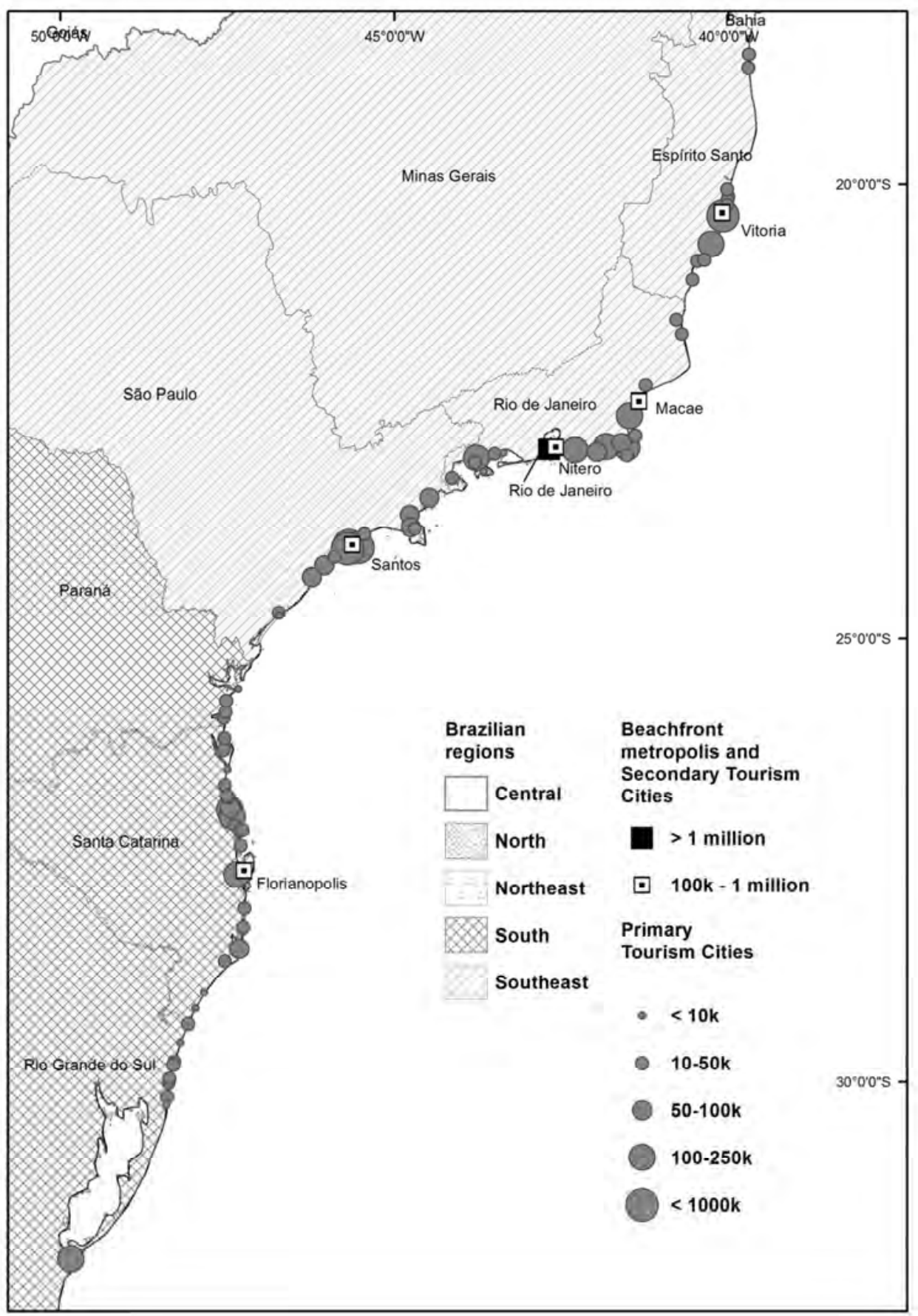

Figure 1: Tourism destinations in southern Brazil (south and southeast regions). 


\section{Page 35 of 38}

2

3

4

5

6

7

8

9

10

11

12

13

14

15

16

17

18

19

20

21

22

23

24

25

26

27

28

29

30

31

32

33

34

35

36

37

38

39

40

41

42

43

44

45

46

47

48

49

50

51

52

53

54

55

56

57

58

59

60

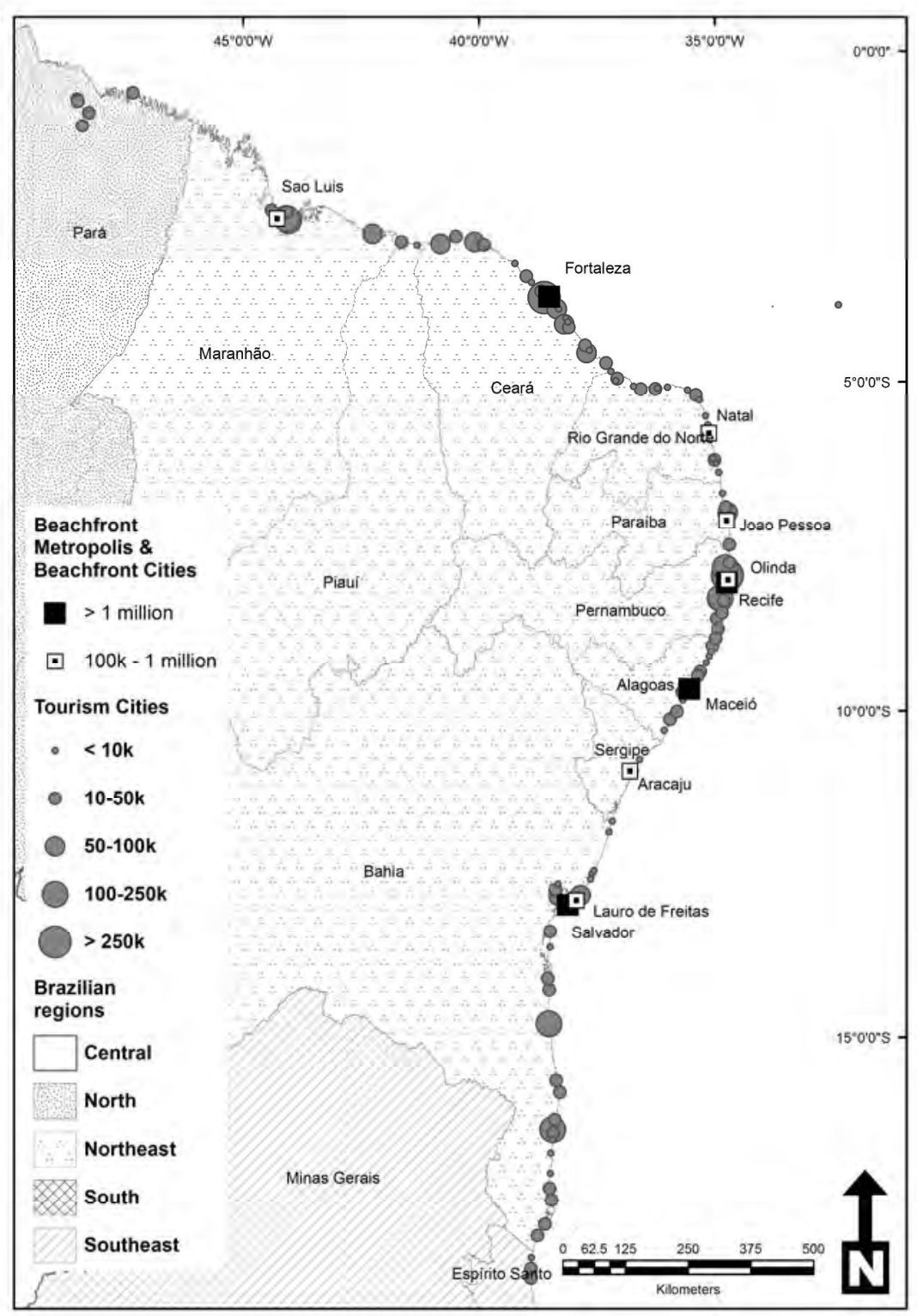

Tourism destinations in Northern Brazil (North and Northeast regions) $296 \times 419 \mathrm{~mm}(300 \times 300 \mathrm{DPI})$ 


\section{Environmental}

- Extensive coastline

- Coastal water temperature

- Climate

- Water quality

- Isolation and scenery

\section{Historical}

- Land settlement

- State capitals are tourism poles

- Affluent societies as a tourism catalyst

- Access

- The beach as a cultural phenomenon

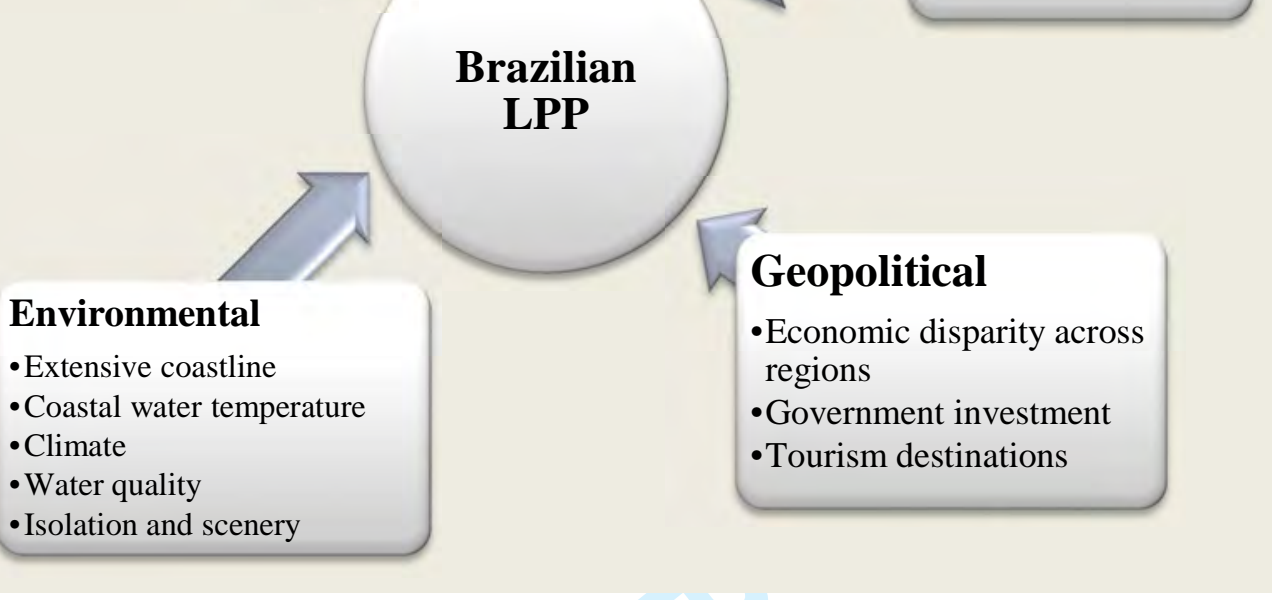

Figure 3: The five factors that influence the contemporary development of the Brazilian LPP 
Table 1. LPP tourism places by type and region based on population numbers.

\begin{tabular}{|c|c|c|c|c|c|c|c|c|}
\hline \multirow[b]{2}{*}{ Region } & \multirow[b]{2}{*}{ BM } & \multirow[b]{2}{*}{ BC } & \multicolumn{4}{|c|}{ TC } & \multirow[b]{2}{*}{$250 \mathrm{~K}>$} & \multirow[b]{2}{*}{ Total } \\
\hline & & & $<10 \mathrm{~K}$ & $\begin{array}{r}10 \mathrm{~K} \text { to } \\
50 \mathrm{~K}\end{array}$ & $\begin{array}{r}50 \mathrm{~K} \text { to } \\
100 \mathrm{~K}\end{array}$ & $\begin{array}{r}100 \mathrm{~K} \text { to } \\
250 \mathrm{~K}\end{array}$ & & \\
\hline $\begin{array}{c}\mathrm{N}+\mathrm{NE} \\
(\%)\end{array}$ & $4(80 \%)$ & $6(60 \%)$ & $38(84 \%)$ & $52(55 \%)$ & $8(50 \%)$ & $6(35 \%)$ & $2(29 \%)$ & $116(59 \%)$ \\
\hline $\begin{array}{c}\mathrm{S}+\mathrm{SE} \\
(\%)\end{array}$ & $1(20 \%)$ & $4(40 \%)$ & $7(16 \%)$ & $43(45 \%)$ & $8(50 \%)$ & $11(65 \%)$ & $5(71 \%)$ & $79(41 \%)$ \\
\hline Total & 5 & 10 & 45 & 95 & 16 & 17 & 7 & 195 \\
\hline
\end{tabular}

$\mathrm{BM}=$ beachfront metropolis; $\mathrm{BC}=$ beachfront city; $\mathrm{TC}=$ tourism city 
Table 2. Tourism investment by state and region projected to open between 2006 and 2012 including the number of hotel rooms and direct jobs associated with these investments

\begin{tabular}{lcrr}
\hline \hline Location & Investment (US\$1,000.00) & \# Rooms & \# Jobs \\
\hline Northeast & $5,606,165(78.5 \%)$ & $45,002(77.9 \%)$ & $49,065(87.7 \%)$ \\
North & $307,032(4.3 \%)$ & $3,423(5.9 \%)$ & $1,189(2.1 \%)$ \\
South & $167,488(2.3 \%)$ & $1,493(2.6 \%)$ & $896(1.6 \%)$ \\
Southeast & $1,060,507(14.9 \%)$ & $7,823(13.5 \%)$ & $4,771(8.5 \%)$ \\
\hline Total Brazil & $\mathbf{7 , 1 4 1 , 1 9 4}$ & $\mathbf{5 7 , 7 4 1}$ & $\mathbf{5 5 , 9 2 1}$ \\
\hline \hline
\end{tabular}

